\title{
Estimation of Reference Evapotranspiration Using Multiple Linear Regression Models
}

\author{
Selcuk Usta (Corresponding author) \\ Department of Construction Technology, Van Yuzuncu Yil University, Van/Turkey \\ E-mail: susta@yyu.edu.tr \\ Serpil Gencoglan \\ Department of Biosystem Eng., \\ Kahramanmaras Sutcu Imam University, Kahramanmaras/Turkey \\ E-mail: sgencoglan@ksu.edu.tr
}

\begin{abstract}
The aim of this study is to estimate the amount of reference evapotranspiration $\left(\mathrm{ET}_{\mathrm{o}}\right)$ by multiple linear regression models (MLRM) developed by using various combinations of air temperature $\left(\mathrm{T}, \mathrm{T}_{\max }, \mathrm{T}_{\min }\right)$ and relative humidity $\left(\mathrm{R}_{\mathrm{H}}\right)$. For this purpose, using Van province climate data $\mathrm{MLRM}_{1}, \mathrm{MLRM}_{2}$ and $\mathrm{MLRM}_{3}$ models have been developed. The regression coefficient $\left(\mathrm{R}^{2}\right)$, defined as the level of indication of the change in $\mathrm{ET}_{\mathrm{o}}$, has been obtained as 0.95 for $\mathrm{MLRM}_{1}, 0.99$ for $\mathrm{MLRM}_{2}$ and MLRM . Root mean square error (RMSE) as an indicator of the deviation of the $\widehat{E T}_{0}$ value estimated by the model from the $\mathrm{ET}_{\mathrm{o}}$ value determined by the FAO 56 Penman Monteith equation, has been determined 0.16 for the $\mathrm{MLRM}_{1}, 0.12$ for the $\mathrm{MLRM}_{2}$ and the $\mathrm{MLRM}_{3}$. It has been found that the models give healthier results in the determination of total plant water consumption $\left(\Sigma E T_{c}\right)$ during the vegetation period rather than daily $\mathrm{ET}_{\mathrm{o}}$ estimation. Only the $\mathrm{MLRM}_{1}$ model with the lowest mean absolute percentage error (MAPE $=10 \%$ ) is recommended for daily $\mathrm{ET}_{\mathrm{O}}$ estimation. It is considered that all MLRM models can be used in $\Sigma \mathrm{ET}_{\mathrm{c}}$ determination with a rate of 5-6\% MAPE and will be a good alternative because they are suitable for the region.
\end{abstract}

Keywords: Evapotranspiration, Air temperature, Relative humidity, Penman Monteith, Regression

DOI: $10.7176 / \mathrm{JSTR} / 5-2-02$

\section{Çoklu Doğrusal Regresyon Modelleri Kullanılarak Referans Evapotranspirasyonun Tahmin Edilmesi}

Özet

Bu çalışmada; hava sıcaklığ $1\left(T, T_{\max }, T_{\min }\right)$ ve oransal nemin $\left(\mathrm{R}_{\mathrm{H}}\right)$ çeşitli kombinasyonları kullanılarak geliştirilen çoklu doğrusal regresyon modelleri (ÇDRM) ile referans evapotranspirasyonun $\left(\mathrm{ET}_{\mathrm{o}}\right)$ tahmin edilmesi amaçlanmıştır. $\mathrm{Bu}$ amaçla Van ili iklim verileri kullanılarak $\mathrm{ÇDRM}_{1}, \mathrm{ÇDRM}_{2}$ ve $\mathrm{ÇDRM}_{3}$ modelleri geliştirilmiştir. $\mathrm{ET}_{\mathrm{o}}$ 'daki değişimin modelle ifade edilme düzeyi olarak tanımlanan regresyon katsayısı $\left(\mathrm{R}^{2}\right) \mathrm{ÇDRM}_{1}$ için $0.95, \mathrm{CCDRM}_{2}$ ve $\mathrm{CCDRM}_{3}$ için 0.99 olarak elde edilmiştir. Modelle tahmin edilen $\widehat{\mathrm{ET}}_{\mathrm{o}}$ değerinin, FAO $56 \mathrm{PM}$ eşitliğiyle belirlenen $\mathrm{ET}_{\mathrm{o}}$ değerinden olan sapma miktarının bir göstergesi olarak karekök ortalama karesel hata $(\mathrm{KOKH}) \mathrm{ÇDRM}_{1}$ için $0.16, \mathrm{ÇDRM}_{2}$ ve $\mathrm{ÇDRM}_{3}$ için 0.12 olarak belirlenmiştir. Modellerin günlük $\mathrm{ET}_{\mathrm{o}}$ tahmininden ziyade, vejetasyon süresi boyunca gerçekleşen toplam bitki su tüketimi $\left(\Sigma E T_{c}\right)$ tayininde daha sağlıklı sonuçlar verdiği görülmüştür. Sadece en düşük ortalama mutlak göreceli hata oranına $(\mathrm{OMGH}=\% 10)$ sahip olan $\mathrm{ÇDRM}_{1}$ modelinin günlük $\mathrm{ET}_{\mathrm{o}}$ tahmininde kullanılması önerilmektedir. Geliştirilen tüm ÇDRM modellerinin \% 5-6 OMGH oranıyla $\Sigma E T_{c}$ tayininde kullanılabilecekleri ve yöreye uygun olmaları nedeniyle iyi bir alternatif olacakları düşünülmektedir.

Anahtar Kelimeler: Evapotranspirasyon, Hava sıcaklığı, Oransal nem, Penman Monteith, Regresyon

5 I P a g e

www.iiste.org 


\section{Giriş}

Bitki sulama suyu ihtiyacının belirlenmesinde, sulama zamanı ve aralıklarının programlanmasında, sulama ve drenaj sistemleri ile göletlerin ve barajların projelendirilmesi ve işletilmesinde, kuraklığın izlenmesi ve hidrolojik modellerin oluşturulmasında dikkate alınan temel veri evapotranspirasyon $\left(\mathrm{ET}_{\mathrm{c}}\right)$ olarak adlandırılan bitki su tüketimidir. Topraktan veya su yüzeyinden gerçekleşen buharlaşma (Evaporasyon) kayıpları ile bitki yaprak yüzeylerinden gerçekleşen terleme (Transpirasyon) kayıplarının toplamı olarak tanımlanan evapotranspirasyon; bitki, toprak, iklim ve işletme biçimi gibi çok sayıda etmenin etkisiyle gerçekleştiğinden dolayı doğadaki en karmaşık olaylardan birisi olarak kabul edilmektedir (Kanber, 2006). Öte yandan Uçak ve Ark., (2013) evapotranspirasyonu doğrudan etkileyen iklimin en önemli parametrelerinin sıcaklık, yağış, rüzgar hızı ve oransal nem olduğunu bildirmişlerdir. Evapotranspirasyon lizimetre ile doğrudan ölçülebildiği gibi bitki, toprak ve iklim özelliklerine dayalı olarak çok sayıda matematiksel yöntemle tahmin edilebilmektedir. (Rana ve Katerji, 2000). Uygulamada daha çok hava sıcaklığı, oransal nem, solar radyasyon, güneşlenme süresi, rüzgar hızı, toprak sıcaklığı ve buharlaşma miktarı gibi iklim parametrelerinin dikkate alındığı yöntemler kullanılmaktadır. $\mathrm{Bu}$ yöntemlerin başlıcaları; Penman Monteith, Pan Evaporation, Hargreaves, Kimberly Penman ve Blaney Criddle yöntemleridir. Sulama ve drenaj sistemlerinin projelendirilmesinde dikkate alınan toplam bitki su tüketiminin tahmin edilmesinde, daha çok uzun süreli periyodlar için sağlıklı sonuçlar veren ve birkaç iklim parametresini kapsayan basit eşitliklerden oluşan ampirik yöntemler kullanılmaktadır. Sulama zamanının planlanmasında dikkate alınan bitki su tüketiminin tahmin edilmesinde ise günlük, haftalık ve on günlük periyodlar için sağlıklı sonuçlar veren, genellikle çok sayıda iklim parametresini içeren karmaşık eşitliklerden oluşan ampirik yöntemler kullanılmaktadır (Doorenbos ve Pruitt, 1977; Lazzara ve Rana, 2010).

Günümüzde bitki su tüketimini tahmin etmek amacıyla, daha çok referans bitki su tüketimi (ETo $)_{0}$ ve bitki katsayısına $\left(\mathrm{k}_{\mathrm{c}}\right)$ dayalı yöntemler tercih edilmektedir. Açık tarla koşullarında referans bitki su tüketimine bağlı olarak bitki su tüketimini belirlemek amacıyla dünya çapında en çok tercih edilen yöntemin Penman Monteith yöntemi olduğu belirtilmektedir (Çetin ve Ark., 2014). Referans bitki su tüketimi $\left(\mathrm{ET}_{\mathrm{o}}\right.$ ); egemen iklimsel koşullarda yetişen ve yeterli düzeyde sulanan, sağlıklı büyüyen, toprağı tamamen gölgeleyen, $12 \mathrm{~cm}$ yüksekliğinde ve taç aerodinamik direnci $70 \mathrm{~s} / \mathrm{m}$ olan çim bitkisinden, albedonun 0.23 olduğu şartlarda gerçekleşen maksimum evapotranspirasyon miktarı olarak tanımlanmaktadır (Allen ve ark., 1998; Sepaskhah ve Andam, 2001; Aydinşakir ve ark., 2003; Amayreh ve Al-Abed, 2005; Er-Raki ve ark., 2008; Ko ve ark., 2009; Katerji ve Rana, 2014; Karaca ve ark., 2017).

Penman Monteith yöntemi kullanılarak herhangi bir bitkinin bitki su tüketimi belirlenmek istendiğinde, referans bitki su tüketiminin su tüketimi belirlenecek bitkinin bitki katsayısı ile çarpılarak düzeltilmesi gereklidir (Doorenbos ve Pruitt, 1977; Aydinşakir ve ark., 2003). Bitki su tüketiminin tahmin edilmesinde, bitki katsayısı değerlerinin kullanılması fikri ilk kez 1968 yılında Jensen tarafından önerilmiştir (Jensen, 1968). Bitki katsayısı deneysel olarak elde edilen, bitkinin fizyolojisini, örtü derecesini ve verilerin derlendiği yöreyi yansıtan bir katsayıdır. Aynı bitki için farklı iklim özelliklerine sahip bölgelerde dikkate alınacak bitki katsayıları farklılıklar göstermektedir. Bitki katsayısı bitkinin büyüme mevsimi boyunca değişkenlik göstermekte olup, bitkinin tozlaşma periyodunda maksimum değerlerine ulaşmaktadır. Bitki su tüketimi bitki ve toprağın karakteristik özellikleri tarafından etkilenmektedir. Su tüketimi hesaplanacak bitkinin boyu ve su kaybına karşı bitki-toprak direnci referans bitkiden (Çim) farklıdır. Bu farklılıkların da dikkate alındığı, en gerçekçi su tüketimi tahminlerinin yapılmasını sağlayan FAO-56 Penman Monteith yöntemi Birleşmiş Milletler Gıda ve Tarım Örgütü (FAO) tarafından 1998 yılında geliştirilerek 56 sayılı Sulama ve Drenaj Yayını ile uygulanmaya başlamıştır (ASCE-EWRI, 2004).

Penman Monteith yönteminin diğer ampirik tahmin yöntemlerine göre daha gerçeğe yakın sonuçlar verdiği yapılan birçok çalışma ile ortaya koyulmuştur. Sulama suyu ihtiyaçlarının Penman Monteith ve Blaney Criddle yöntemlerine göre ayrı ayrı hesapladığ 120 sulama şebekesi üzerinde yapılan bir çalışmada, incelenen şebekelerin \% 43'ünde önemli farklılıklar olduğu ortaya koyulmuştur (Beyribey ve ark., 1997). Yarı kurak bir bölgede yapılan bir çalışmada, yukarıda verilen matematiksel yöntemler ile belirlenen su tüketimi değerleri lizimetre ile kontrol edilmiş ve en gerçekçi sonucu Penman Monteith yönteminin verdiği tespit edilmiştir (Dehghanisanij ve ark., 2004). Gediz Havzasında pamuk ekimi yapılan alanlarda matematiksel yöntemler ile hesaplanan sulama suyu ihtiyacı, su bütçesi yöntemi ile karşılaştırılmış ve Penman Monteith yönteminin gerçeğe en yakın sonucu verdiği tespit edilmiştir (Beyazgül ve ark., 2000).

Referans bitki su tüketiminin ( $\mathrm{ET}_{\mathrm{o}}$ ) tahmin edilmesi amacıyla birçok yazılım geliştirilmiştir (Karaca ve ark., 2017). Bu amaçla kullanılan en yaygın bilgisayar yazılımları DAILY ET (Hess, 1996), DSS_ET

6 I P a g e 


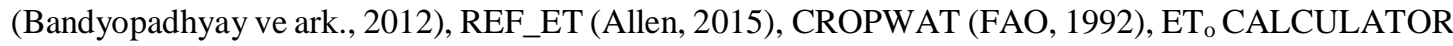
(Raes, 2012), IAM_ET (Steduto ve Snyder, 1998) ve ET0 (Gocic ve Trajkovic, 2010) yazılımlarıdır. Maksimum ve minimum hava sıcaklıkları, oransal nem, rüzgar hızı ve günlük güneşlenme süresi iklim parametrelerinin giriş değişkenleri olarak dikkate alındığı CROPWAT yazılımı referans bitki su tüketiminin tahmin edilmesi amacıyla araştırmacılar tarafından sıkça kullanılmaktadır. Penman Monteith eşitliğini kullanarak aylık ortalama günlük toplam $\mathrm{ET}_{\mathrm{o}}$ değerlerini hesaplayabilen CROPWAT yazılımında iklim parametreleri dışında rakım, enlem ve boylam değerleri de giriş değişkeni olarak dikkate alınmaktadır.

Alternatif bitki su tüketimi tahmin yöntemlerinin geliştirilmesi amacıyla birçok çalışma yapılmıştır. Doğan Demir ve Meral (2016), Bingöl koşullarında referans bitki su tüketiminin doğrudan ve farklı tahmin yöntemleri kullanılarak belirlenmesi amacıyla yürüttükleri bir çalışmada; FAO Penman Monteith yöntemi ile elde edilen bitki su tüketimi değerlerinin, mini lizimetre ile belirlenen gerçek bitki su tüketimi değerlerine oldukça yakın sonuçlar verdiğini tespit etmişlerdir. Aynı çalışmada bitki su tüketimi üzerinde etkili olan sıcaklık, oransal nem, rüzgar hızı, güneşlenme süresi ve buharlaşma parametrelerinin bağımsız değişken olarak kullanıldığ 1 bir çoklu regresyon modeli geliştirmişlerdir. Yüksek korelasyon katsayısına sahip bu regresyon modelinin diğer ampirik eşitliklere kıyasla kullanımının daha kolay ve doğrudan yöreye uyumlu olması nedeniyle iyi bir alternatif olduğunu belirtmişlerdir. Kaya ve ark. (2013), Erzurum ve Iğdır koşullarında sıcaklık verilerini kullanarak referans evapotranspirasyonu (ET ${ }_{\mathrm{o}}$ ) belirlemek amacıyla yapay sinir ağı modelleri (YSA 1, YSA 2) geliștirmişlerdir. Maksimum sıcaklık, minimum sıcaklık, ekstraterrestrial radyasyon ve takvim günü girdilerinin değişken olarak dikkate alındığı bu modellerle hesaplanan $\mathrm{ET}_{\mathrm{o}}$ değerlerini, FAO 56 Penman Monteith eşitliği ile hesaplanan $\mathrm{ET}_{\mathrm{o}}$ değerleri ile kıyaslayıp regresyon katsayılarını Erzurum için $\mathrm{R}^{2}=0.99$, Iğdır için $\mathrm{R}^{2}=0.985-0.986$ olarak elde etmişlerdir. Geliştirdikleri modellerle referans evapotranspirasyonun yeterli doğrulukta tahmin edilebileceğini belirtmişlerdir. Kişi ve Afşar (2010), tava buharlaşma miktarını tahmin etmek amacıyla nem, ortalama sicaklık, minimum sicaklık ve maksimum sicaklık parametrelerinin dört farklı kombinasyonunu kullanarak çoklu doğrusal regresyon modelleri geliştirmişlerdir. Kayseri, Kırşehir, Nevşehir ve Yozgat şehirlerinin iklim verilerini kullanarak yaptıkları çalışmada iklim parametrelerinin tamamının bağımsız değişken olarak dikkate alındığ 1 çoklu doğrusal regresyon modelinin gerçeğe en yakın sonuçları verdiğini, bu model için korelasyon katsayısının 0.6069-0.7742 aralığında, ortalama mutlak hatanın ise 1.0231-1.7864 mm aralığında değiştiğini belirtmişlerdir. Kodal (1982), İç Anadolu koşullarına uygun bitki su tüketimi tahmin yöntemini belirlemek amacıyla yaptığı bir çalışmada Ankara, Eskişehir ve Konya Köy Hizmetleri Araştırma Enstitülerinde tarla denemeleri ile aylık dönemler için ölçülen bitki su tüketimi değerlerini Blaney-Criddle, Penman Monteith ve Jensen-Haise yöntemleriyle tahmin edilen su tüketimi değerleri ile karşılaştırmış ve yöre koşullarında daha sağlıklı sonuçlar veren Kodal eşitliğini geliştirmiştir (Kodal, 1982).

T.C. Gıda, Tarım ve Hayvancılık Bakanlığı ile Orman ve Su İşleri Bakanlığı tarafından araştırmacılara ve üreticilere güvenilir bir kaynak oluşturmak amacıyla "Türkiye'de Sulanan Bitkilerin Su Tüketim Rehberi" hazırlanmıştır. Bu rehberde; ülkemizin iklimi, arazi yapısı ve coğrafi özellikleri dikkate alınarak bölgeler oluşturulmuştur. İklim özellikleri benzerlik gösteren şehirler aynı bölgelerde toplanmıştır. Rehberde bölge ve şehir düzeyinde, FAO 56 Penman Monteith yöntemine göre belirlenen aylık ortalama günlük referans bitki su tüketimi (ETo $)$ değerleri, çeşitli bitkiler için vejetasyon süresi boyunca dikkate alınacak bitki katsayıları $\left(\mathrm{k}_{\mathrm{c}}\right)$ ve on günlük periyodlar için bitki su tüketimi miktarları $\left(\mathrm{ET}_{\mathrm{c}}\right)$ verilmiştir (Anonim, 2016).

Bitki su tüketimi tahmininde araştırmacılar tarafından en çok tercih edilen yöntem FAO 56 Penman Monteith yöntemidir. Bu yöntemde hava sıcaklığ $1(T)$, oransal nem $\left(R_{H}\right)$, solar radyasyon $\left(R_{S}\right)$, rüzgar hızı (U), günlük güneşlenme süresi (n) ve toprak 1sı akısı $(\mathrm{G})$ iklim parametreleri giriş değişkeni olarak dikkate alınmaktadır. Bu iklim parametrelerinden sadece $T$ ve $R_{H}$ Meteoroloji Genel Müdürlüğü tarafından yerel düzeyde yapılan ölçümlerle belirlenebilmektedir. $T$ ve $R_{H}$ dışındaki $R_{S}, U, n$ ve $G$ iklim parametreleri ise ülkemiz genelinde yerel düzeyde devamlı ve düzenli olarak ölçülememektedir. $\mathrm{R}_{\mathrm{S}}, \mathrm{U}$, n ve $\mathrm{G}$ iklim parametreleri daha çok şehir merkezleri düzeyinde ölçülebilmektedir. Buna karşın tarımsal üretim faaliyetleri daha çok yerel düzeydeki kırsal alanlarda yürütülmektedir. Dolayısıyla yerel düzeyde ölçülen günlük iklim verilerine ihtiyaç duyulmaktadır. Bu durum Penman Monteith yönteminin kullanımı önündeki tek engel olarak görülebilir. Yerel düzeyde günlük iklim verileri portatif iklim istasyonları ile ölçülebilmektedir. Ancak bu iklim istasyonlarının satış bedelleri üreticilerin satın alma gücünün çok üzerinde olmaktadır. Bu çalışmada; yerel düzeyde kolay ulaşılabilir iklim parametreleri olan ortalama hava sıcaklığ 1 , maksimum hava sıcaklığ 1 ve minimum hava sıcaklığı parametreleri ile oransal nemin çeşitli kombinasyonları kullanılarak geliştirilen çoklu doğrusal regresyon modelleri ile referans evapotranspirasyonun tahmin edilmesi amaçlanmıştır.

7 | P a g e

www.iiste.org 
Vol.5, No.2, 2019

\section{Materyal ve Metot}

Matematiksel konum olarak $38^{\circ} 28^{\prime}(\mathrm{N})$ kuzey enleminde ve $43^{\circ} 20^{\prime}$ (E) batı boylaminda bulunan, y1ll1k $387.2 \mathrm{~mm}$ toplam yağış miktarı ile yarı kurak iklim kuşağında yer alan ve rakımı $1727 \mathrm{~m}$ olan Van ilinin iklim verileri bu çalışmanın materyalini oluşturmuştur. Çoklu doğrusal regresyon modellerinin geliştirilmesi kapsamında yapılan referans bitki su tüketimi $\left(\mathrm{ET}_{\mathrm{o}}\right)$ hesaplamalarında Tablo 1'de verilen Van ili uzun yıllar ortalaması iklim verileri kullanılmıştır (DMİ, 2018).

Tablo 1. Van ilinin 1938-2017 yılları arası iklim verilerinin aylık ortalama değerleri

\begin{tabular}{|l|l|l|l|l|l|l|l|l|l|l|l|l|}
\hline Aylar & 1 & 2 & 3 & 4 & 5 & 6 & 7 & 8 & 9 & 10 & 11 & 12 \\
\hline $\mathrm{T}\left({ }^{\circ} \mathrm{C}\right)$ & -3.1 & -2.6 & 1.5 & 7.7 & 13.1 & 18.2 & 22.2 & 22.1 & 17.8 & 11.2 & 4.9 & -0.5 \\
\hline $\mathrm{T}_{\max }\left({ }^{\circ} \mathrm{C}\right)$ & 1.8 & 2.5 & 6.4 & 12.7 & 18.4 & 23.8 & 28.1 & 28.4 & 24.2 & 17.3 & 10.2 & 4.3 \\
\hline $\mathrm{T}_{\min }\left({ }^{\circ} \mathrm{C}\right)$ & -7.6 & -7.2 & -2.9 & 2.5 & 6.9 & 10.7 & 14.5 & 14.5 & 10.6 & 5.6 & 0.3 & -4.6 \\
\hline $\mathrm{n}$ (saat) & 4.5 & 5.3 & 6.0 & 7.2 & 9.3 & 11.7 & 12.1 & 11.4 & 9.8 & 7.0 & 5.5 & 4.3 \\
\hline $\mathrm{R}_{\mathrm{H}}$ (\%) & 68 & 69 & 67 & 61 & 57 & 50 & 45 & 43 & 45 & 59 & 66 & 68 \\
\hline $\begin{array}{l}\mathrm{U}_{2} \\
(\mathrm{~km} / \text { gün) }\end{array}$ & 143 & 143 & 143 & 162 & 149 & 149 & 149 & 156 & 156 & 143 & 143 & 136 \\
\hline
\end{tabular}

Doğrusal regresyon modellerinin oluşturulması kapsamında yapılan istatiksel uygulamalarda giriş değişkenleri olarak; hava sıcaklığının ortalama $(T)$, maksimum $\left(T_{\max }\right)$, minimum $\left(\mathrm{T}_{\min }\right)$ değerleri ile oransal nem $\left(\mathrm{R}_{\mathrm{H}}\right)$ değerleri dikkate alınmıştır. Bu iklim parametreleri ile referans evapotranspirasyon $\left(E_{\mathrm{o}}\right)$ arasındaki istatistiki ilişkileri ortaya koyabilmek amacıyla ilk olarak günlük referans evapotranspirasyon değerlerinin aylık ortalamaları hesaplanmıştır. Aylık uzun yıllar ortalaması iklim

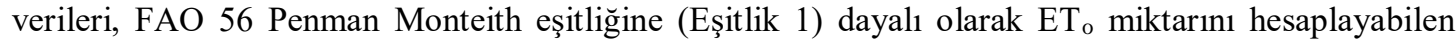
CROPWAT yazılımına girilerek günlük referans evapotranspirasyon değerlerinin aylık ortalamaları belirlenmiştir. Çalışmada, bu değerler gerçek referans evapotranspirasyon $\left(\mathrm{ET}_{\mathrm{o}}\right)$ değerleri olarak kabul edilmiştir. FAO 56 Penman Monteith eşitliğinin bileşenleri Şekil 1'de gösterilmiştir. Bitki su tüketimi $\left(\mathrm{ET}_{\mathrm{c}}\right)$ hesaplamalarında ise Eşitlik 2 kullanılmıştır (ASCE-EWRI, 2004; Pereira ve ark., 2015).

$\mathrm{ET}_{\mathrm{o}}=\frac{0,408 \cdot \Delta \cdot\left(\mathrm{R}_{\mathrm{n}}-\mathrm{G}\right)+\gamma \frac{900}{\mathrm{~T}+273} \mathrm{U}_{2} \cdot\left(\mathrm{e}_{\mathrm{s}}-\mathrm{e}_{\mathrm{a}}\right)}{\Delta+\gamma \cdot\left(1+0,34 \cdot \mathrm{U}_{2}\right)}$

$\mathrm{ET}_{\mathrm{c}}=\mathrm{ET}_{\mathrm{o}} \cdot \mathrm{k}_{\mathrm{c}}$

Eşitlik 1, Eşitlik 2 ve Şekil 1'de; $\mathrm{ET}_{\mathrm{o}}$ : Referans evapotranspirasyon (mm/gün), k $\mathrm{k}_{\mathrm{c}}$ : Bitki katsayısı, $\mathrm{ET}_{\mathrm{c}}$ : Bitki su tüketimi (mm/gün), $\Delta$ : Doygun buhar basıncı eğrisinin eğimi $\left(\mathrm{kPa} /{ }^{\circ} \mathrm{C}\right), \mathrm{R}_{\mathrm{n}}$ : Bitki yüzeyindeki net radyasyon $\left(\mathrm{MJ} / \mathrm{m}^{2} /\right.$ gün$)$, G: Topraktaki $1 \mathrm{~s} 1$ akısı $\left(\mathrm{MJ} / \mathrm{m}^{2} /\right.$ gün$), \quad \gamma$ : Psikometrik sabite $\left(\mathrm{kPa} /{ }^{\circ} \mathrm{C}\right), \mathrm{T}$ : Ortalama hava sıcaklığ $1\left({ }^{\circ} \mathrm{C}\right), \mathrm{T}_{\max }, \mathrm{T}_{\min }$ : Ortalama en yüksek ve en düşük hava sıcaklıkları $\left({ }^{\circ} \mathrm{C}\right), \mathrm{U}_{2}: 2 \mathrm{~m}$ yükseklikte ölçülen rüzgar hızı (m/s), $U_{Z}$ : Toprak yüzeyinden $Z$ yükseklikte ölçülen rüzgar hızı $(\mathrm{m} / \mathrm{s}), Z^{*}$ : Rüzgar hızının ölçüldüğü yükseklik (m), e : Doygun buhar basıncı $(\mathrm{kPa}), \mathrm{e}_{\mathrm{a}}$ : Gerçek buhar basıncı $(\mathrm{kPa})$, $\mathrm{R}_{\mathrm{H}}$ : Oransal nem (\%), $\mathrm{R}_{\mathrm{ns}}$ : Güneşten gelen net kısa dalga radyasyon $\left(\mathrm{MJ} / \mathrm{m}^{2} /\right.$ gün), $\mathrm{R}_{\mathrm{nl}}$ : Dünyadan giden net uzun dalga radyasyon $\left(\mathrm{MJ} / \mathrm{m}^{2} /\right.$ gün), $\propto$ : Yansitma katsayısı (Albedo), $R_{S}$ : Yeryüzüne ulaşan kısa dalga radyasyon $\left(\mathrm{MJ} / \mathrm{m}^{2} /\right.$ gün$), \mathrm{R}_{\mathrm{a}}$ : Atmosferin dış yüzüne ulaşan radyasyon $\left(\mathrm{MJ} / \mathrm{m}^{2} / \mathrm{gün}\right), \mathrm{a}_{\mathrm{s}}$, $\mathrm{b}_{\mathrm{s}}$ : Regresyon katsayıları, n: Gerçek güneşlenme süresi (saat), N: Olası maksimum güneşlenme süresi (saat), $\sigma:$ Stefan Boltzmann katsayısı (4.903 $10^{-9} \mathrm{MJ} / \mathrm{K}^{4} / \mathrm{m}^{2} /$ gün), $\mathrm{R}_{\mathrm{so}}$ : Açık gökyüzü radyasyonu $\left(\mathrm{MJ} / \mathrm{m}^{2} / g u ̈ n\right), ~ Z$ : Rakım (m), P: Atmosferik basınç (kPa), $\mathrm{C}_{\mathrm{p}}$ : Sabit basınç altındaki özgül ısı $\left(\mathrm{MJ} / \mathrm{kg}^{\circ} \mathrm{C}\right), \lambda$ : Buharlaşma gizli 1Sısı $(\mathrm{MJ} / \mathrm{kg}) \varepsilon$ : Su buharı moleküler ağırlığının kuru hava ağırlığına oranı ve $\mathrm{e}^{\mathrm{o}}{ }_{(\operatorname{Tmax})}, \mathrm{e}^{\mathrm{o}}{ }_{(\mathrm{Tmin})}$ : En yüksek ve en düşük hava sıcaklıklarındaki doygun buhar basıncını $(\mathrm{kPa})$ ifade etmektedir. $20^{\circ} \mathrm{C}$ hava sıcaklığında;

8 I P a g e www.iiste.org 
$\mathrm{C}_{\mathrm{P}}=1.01310^{-3} \mathrm{MJ} / \mathrm{kg}^{\circ} \mathrm{C}, \varepsilon=0.622, \lambda=2.45 \mathrm{MJ} / \mathrm{kg}$ alınabilmektedir. Bu değerlerin pisikometrik sabite eşitliğine uygulanması ile $\gamma=0.66510^{-3} \mathrm{P}$ elde edilmektedir (ASCE-EWRI, 2004; Pereira ve ark., 2015).

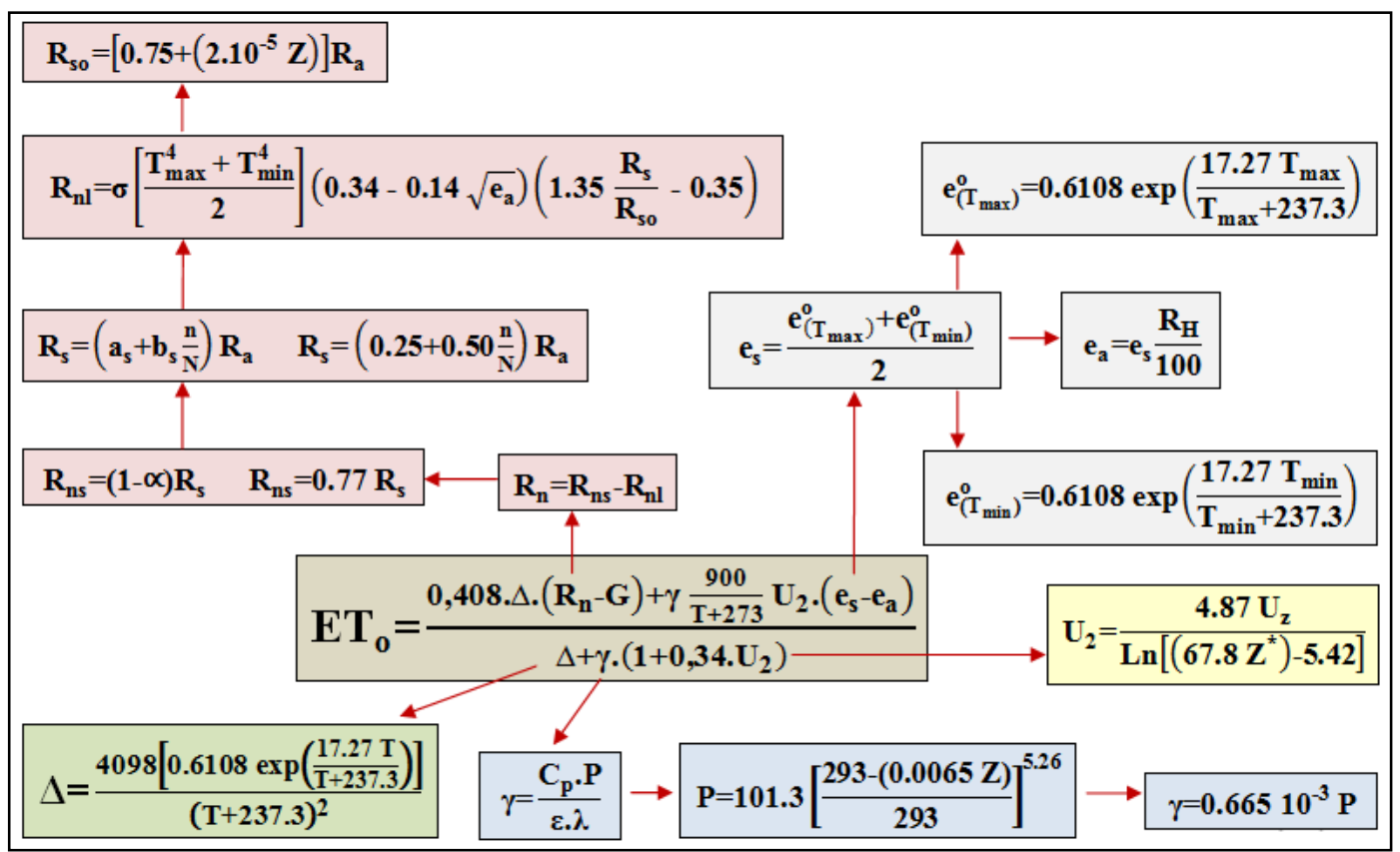

Şekil 1. FAO 56 Penman Monteith eşitliği ve bileşenleri

$\mathrm{T}, \mathrm{T}_{\max }, \mathrm{T}_{\min }$ ve $\mathrm{R}_{\mathrm{H}}$ iklim parametreleri ile Referans evapotranspirasyon $\left(\mathrm{ET}_{\mathrm{o}}\right.$ ) arasindaki anlaml istatistiksel ilişkilerin ortaya koyulmasında doğrusal regresyon analizi yöntemi kullanılmıştır (Eşitlik 3). Dolayısıyla bağımlı değişken olarak $\mathrm{ET}_{\mathrm{o}}$, bağımsız değişkenler olarak da $\mathrm{T}, \mathrm{T}_{\max }, \mathrm{T}_{\min }$ ve $\mathrm{R}_{\mathrm{H}}$ değerleri dikkate alınmıştır. $T, T_{\max }, T_{\min }$ ve $R_{H}$ bağımsız değişkenlerinin çeşitli kombinasyonları kullanılarak üç adet çoklu doğrusal regresyon modeli (ÇDRM) geliştirilmiştir. İstatiksel hesaplamalar için EXCEL programı kullanılmıştır. Bu çalışma kapsamında geliştirilen çoklu doğrusal regresyon modelleri ve bu modellerin oluşturulmasında dikkate alınan bağımsız değişkenler Tablo 2'de verilmiştir. Her bir model için, $\mathrm{ET}_{\mathrm{o}}$ tahmininde kullanılabilecek eşitliklerinin geliştirilmesi hedeflenmiştir (Büyüköztürk, 2003).

$\widehat{Y}=a+\left(b_{1} \cdot X_{1}\right)+\left(b_{2} \cdot X_{2}\right)+\left(b_{3} \cdot X_{3}\right)+\left(b_{4} \cdot X_{4}\right)+\ldots \ldots \ldots+\left(b_{n} \cdot X_{n}\right)$

Eşitliklerde; $\widehat{\mathrm{Y}}$ : Bağımlı değişkenin tahmin edilen değerini $\left(\widehat{\mathrm{ET}}_{\mathrm{o}}\right)$ ifade etmektedir. a: Tahmin eşitliğinin sabit değeridir. $b_{1}, b_{2}, b_{3}, b_{4} \ldots, b_{n}$ : Doğrusal regresyon analizinde eğimler sabit tutulduğunda ilgili bağımsız değişkendeki birim artışa karşılık, bağımlı değişkende meydana gelen değişim miktarını ifade etmektedir. Kısmi eğim veya kısmi regresyon katsayısı olarak da adlandırılmaktadır. $\mathrm{X}_{1}, \mathrm{X}_{2}, \mathrm{X}_{3}$, $\mathrm{X}_{4} \ldots, \mathrm{X}_{\mathrm{n}}$ : Doğrusal regresyon analizindeki bağımsız değişkenleri ifade etmektedir.

Tablo 2. Çoklu doğrusal regresyon analizi modelleri

\begin{tabular}{|l|c|c|}
\hline Model & Bağımsız değişkenler & Tahmin eşitliği \\
\hline ÇDRM 1 & $\mathrm{X}_{1}: \mathrm{T}, \mathrm{X}_{2}: \mathrm{R}_{\mathrm{H}}$ & $\widehat{\mathrm{ET}}=\mathrm{a}+\left(\mathrm{b}_{1} \cdot \mathrm{T}\right)+\left(\mathrm{b}_{2} \mathrm{R}_{\mathrm{H}}\right)$ \\
\hline ÇDRM $_{2}$ & $\mathrm{X}_{1}: \mathrm{T}, \mathrm{X}_{2}: \mathrm{T}_{\max }, \mathrm{X}_{3}: \mathrm{T}_{\min }$ & $\widehat{\mathrm{ET}_{\mathrm{o}}}=\mathrm{a}+\left(\mathrm{b}_{1} \cdot \mathrm{T}\right)+\left(\mathrm{b}_{2} \cdot \mathrm{T}_{\max }\right)+\left(\mathrm{b}_{3} \cdot \mathrm{T}_{\min }\right)$ \\
\hline $\mathrm{ÇDRM}_{3}$ & $\mathrm{X}_{1}: \mathrm{T}, \mathrm{X}_{2}: \mathrm{T}_{\max }, \mathrm{X}_{3}: \mathrm{T}_{\min }, \mathrm{X}_{4}: \mathrm{R}_{\mathrm{H}}$ & $\widehat{\mathrm{ET}_{\mathrm{o}}}=\mathrm{a}+\left(\mathrm{b}_{1} \cdot \mathrm{T}\right)+\left(\mathrm{b}_{2} \cdot \mathrm{T}_{\max }\right)+\left(\mathrm{b}_{3} \cdot \mathrm{T}_{\min }\right)+\left(\mathrm{b}_{4} \cdot \mathrm{R}_{\mathrm{H}}\right)$ \\
\hline
\end{tabular}

Bağımlı değişken olan referans evapotranspirasyon (ETo $)$ ile bağımsız değişkenler $\left(\mathrm{T}, \mathrm{T}_{\max }, \mathrm{T}_{\min }, \mathrm{R}_{\mathrm{H}}\right)$ arasındaki ilişki düzeyini belirlemek amacıyla, Eşitlik 4 kullanılarak her bir modelin korelasyon katsayısı belirlenmiştir. Ayrıca, bağımlı değişkendeki değişimin ne kadarının bağımsız değişkenler tarafindan 
açıklandığını ifade etmek amacıyla Eşitlik 5 kullanılarak her bir modelin regresyon katsayısı belirlenmiştir (Akgül ve Çevik, 2003). ÇDRM modelleri ile hesaplanan referans evapotranspirasyon $\left(\widehat{E T}_{\mathrm{o}}\right)$ değerleri ile CROPWAT yazılımı kullanılarak hesaplanan gerçek referans evapotranspirasyon $\left(\mathrm{ET}_{\mathrm{o}}\right)$ değerleri arasındaki farkın bir ifadesi olarak Eşitlik 6 ile standart hata miktarları belirlenmiştir (Köksal, 1985).

$\mathrm{r}=\sqrt{\frac{\sum_{\mathrm{i}=1}^{\mathrm{n}}\left(\widehat{\mathrm{Y}}_{\mathrm{i}^{-}} \overline{\mathrm{Y}}_{\mathrm{i}}\right)^{2}}{\sum_{\mathrm{i}=1}^{\mathrm{n}}\left(\mathrm{Y}_{\mathrm{i}}-\overline{\mathrm{Y}}_{\mathrm{i}}\right)^{2}}}$

$\mathrm{R}^{2}=\frac{\sum_{\mathrm{i}=1}^{\mathrm{n}}\left(\widehat{\mathrm{Y}}_{\mathrm{i}}-\overline{\mathrm{Y}}_{\mathrm{i}}\right)^{2}}{\sum_{\mathrm{i}=1}^{\mathrm{n}}\left(\mathrm{Y}_{\mathrm{i}} \overline{\mathrm{Y}}_{\mathrm{i}}\right)^{2}}$

$\mathrm{S}=\sqrt{\frac{\sum_{\mathrm{i}=1}^{\mathrm{n}}\left(\mathrm{Y}_{\mathrm{i}}-\widehat{\mathrm{Y}}_{\mathrm{i}}\right)^{2}}{\mathrm{n}-\mathrm{k}}}$

Eşitliklerde; r: Korelasyon katsayısını, $\mathrm{R}^{2}$ : Regresyon katsayısını, $\widehat{\mathrm{Y}}_{\mathrm{i}}$ : Bağımlı değişkenin modellerle tahmin edilen değerini $\left(\widehat{E T}_{\mathrm{o}}\right), \mathrm{Y}_{\mathrm{i}}$ : Bağımlı değişkenin gerçek değerini $\left(\mathrm{ET}_{\mathrm{o}}\right), \overline{\mathrm{Y}}_{\mathrm{i}}$ : Bağımlı değişkenin gerçek değerlerinin aritmetik ortalamasını, n: Gözlem sayısını (Bir yıllık veri seti için n=12 alınmıştır), S: Standart hatayı, k: Bağımlı ve bağımsız değişkenlerin toplam sayısını ifade etmektedir. ÇDRM ${ }_{1}$ için $\mathrm{k}=3$, ÇDRM 2 için $\mathrm{k}=4$ ve $\mathrm{ÇDRM}_{3}$ için $\mathrm{k}=5$ değerleri dikkate alınmıştır.

Regresyon modellerinde, bağımlı değişken ( $\left.E T_{0}\right)$ ile bağımsız değişkenler $\left(T, T_{\max }, T_{\min }, R_{H}\right)$ arasında doğrusal bir ilişki olup olmadığını test etmek amacıyla aşağıda verilen $H_{o}$ ve $H_{1}$ hipotezleri oluşturulmuştur. Eşitlik 7 ve Eşitlik 8 kullanılarak \% 95 güven aralığında ve \% $5(\alpha=0.05)$ anlamlılık düzeyinde $t$ ve f testleri yapılmıştır. Eşitlik 9 kullanılarak $t$ ve f değerlerinin uygunluğu kontrol edilmiştir. Testlerin sonuçlarına göre hipotezler değerlendirilmiştir. Testlerden elde edilen $t$ ve $f$ değerleri $t_{\text {kritik }}$ ve $\mathrm{f}_{\text {kritik }}$ değerleri ile karşılaştırılarak $\mathrm{H}_{\mathrm{o}}$ ve $\mathrm{H}_{1}$ hipotezlerinden hangisinin kabul edileceği, hangisinin reddedileceği belirlenmiştir. Karşılaştırma sonucunda $t>t_{\text {kritik }}$ ve $f>f_{\text {kritik }}$ olması durumunda $H_{o}$ hipotezi reddedilerek $\mathrm{H}_{1}$ hipotezinin kabul edileceği, $\mathrm{t}<\mathrm{t}_{\text {kritik }}$ ve $\mathrm{f}<\mathrm{f}_{\text {kritik }}$ olmas1 durumunda ise $\mathrm{H}_{1}$ hipotezi reddedilerek $\mathrm{H}_{\mathrm{o}}$ hipotezinin kabul edileceği öngörülmüştür (Ünver ve Gamgam, 1999). yoktur.

$\mathrm{H}_{\mathrm{o}}$ : Bağımlı değişken ( $\left(\mathrm{T}_{\mathrm{o}}\right)$ ile bağımsız değişkenler $\left(\mathrm{T}, \mathrm{T}_{\max }, \mathrm{T}_{\min }\right.$ ) arasında doğrusal bir ilişki

$$
\left[\mathrm{H}_{\mathrm{o}}: \mathrm{b}_{1}=\mathrm{b}_{2}=\mathrm{b}_{3}=0\right]
$$
vardir.

$\mathrm{H}_{1}$ : Bağımlı değişken ( $\left.\mathrm{ET}_{\mathrm{o}}\right)$ ile bağımsız değişkenler $\left(\mathrm{T}, \mathrm{T}_{\max }, \mathrm{T}_{\min }\right)$ arasında doğrusal bir ilişki

$$
\left[\mathrm{H}_{\mathrm{o}}: \mathrm{b}_{1}=\mathrm{b}_{2}=\mathrm{b}_{3} \neq 0\right]
$$

$\mathrm{t}=\frac{\mathrm{r} \cdot \sqrt{\mathrm{n}-2}}{\sqrt{1-\mathrm{r}^{2}}}$

$\mathrm{f}=\frac{\sum_{\mathrm{i}=1}^{\mathrm{n}}\left(\widehat{\mathrm{Y}}_{\mathrm{i}}-\overline{\mathrm{Y}}_{\mathrm{i}}\right)^{2} \cdot(\mathrm{n}-2)}{\sum_{\mathrm{i}=1}^{\mathrm{n}}\left(\mathrm{Y}_{\mathrm{i}}-\widehat{\mathrm{Y}}_{\mathrm{i}}\right)^{2}}$

$\mathrm{f}=\mathrm{t}^{2}$

$\mathrm{f}_{\text {kritik }}=\mathrm{t}_{\text {kritik }}^{2}$ 
Referans evapotranspirasyonun gerçek değerleri $\left(\mathrm{ET}_{\mathrm{o}}\right)$ ile ÇDRM modelleri kullanılarak hesaplanan tahmini değerlerini $\left(\widehat{E T}_{\mathrm{o}}\right)$ karşılaştırma kriteri olarak, karekök ortalama karesel hata $(\mathrm{KOKH})$ ve ortalama mutlak göreceli hata oranı $(\mathrm{OMGH})$ değerleri dikkate alınmıştır. Her iki hata miktarının da sıfıra yaklaşması, ele alınan modelin tahmin yeteneğinin artması anlamına gelmektedir. KOKH ve OMGH değerlerinin belirlenmesinde sırasıyla Eşitlik 10 ve Eşitlik 11 kullanılmıştır (Sing ve ark., 2009).

$\mathrm{KOKH}=\sqrt{\frac{1}{\mathrm{n}} \sum_{\mathrm{i}=1}^{\mathrm{n}}\left(\mathrm{Y}_{\mathrm{i}}-\widehat{\mathrm{Y}}_{\mathrm{i}}\right)^{2}}$

$\mathrm{OMGH}=\frac{1}{\mathrm{n}} \sum_{\mathrm{i}=1}^{\mathrm{n}}\left(\frac{\left|\mathrm{Y}_{\mathrm{i}}-\widehat{\mathrm{Y}}_{\mathrm{i}}\right|}{\mathrm{Y}_{\mathrm{i}}} 100\right)$

Uzun yıllar ortalaması iklim verileri kullanılarak geliştirilen $\mathrm{CCDRM}_{1}, \mathrm{CCDRM}_{2}$ ve ÇDRM $\mathrm{C}_{3}$ modellerinin Van koşullarında kullanılabilirliklerini test etmek amacıyla iki kriter ele alınmıştır. Birinci kriter olarak, modellerin günlük referans bitki su tüketimi $\left(\mathrm{ET}_{\mathrm{o}}\right)$ tahmininde kullanılabilirlikleri test edilmiştir. $\mathrm{Bu}$ amaçla, Van yöresinde 2016 yılının Mayıs, Haziran, Temmuz, Ağustos ve Eylül aylarının on beşinci günlerinde meydana gelen günlük $\mathrm{ET}_{\mathrm{o}}$ miktarları önce FAO 56 Penman Monteith eşitliğiyle, daha sonra modellerle hesaplanarak elde edilen değerler karşılaştırılmıştır. Hesaplamalarda Tablo 3'de verilen iklim verileri kullanılmıştır (DMİ, 2018). İkinci kriter olarak, modellerin vejetasyon süresi boyunca meydana gelebilecek toplam bitki su tüketimi $\left(\Sigma E T_{c}\right)$ miktarının belirlenmesinde kullanılabilirlikleri test edilmiştir. Bu amaçla Türkiye'de Sulanan Bitkilerin Su Tüketim Rehberinden faydalanılmıştır (Anonim, 2016). İlk olarak modeller ile tahmin edilen $\widehat{E T}_{0}$ değerleri, Van için Su Tüketim Rehberinde verilen $\mathrm{ET}_{\mathrm{o}}$ değerleri ile karşılaştırılmıştır (Tablo 4). Daha sonra, Van ilinde yetiştirilen ceviz bitkisinin vejetasyon süresi boyunca meydana gelebilecek toplam bitki su tüketimi önce modellerle, daha sonra Su Tüketim Rehberine göre belirlenerek elde edilen $\widehat{\Sigma E T}_{\mathrm{c}}$ ve $\Sigma E T_{\mathrm{c}}$ değerleri karşılaştırılmıştır. Ceviz bitkisinin bitki katsayıları $\left(\mathrm{k}_{\mathrm{c}}\right)$ Tablo 4'den alınmıştır.

Tablo 3. Van ili 2016 yılı Mayıs- Eylül aylarının on beşinci günlerine ait iklim verileri

\begin{tabular}{|l|l|l|l|l|l|}
\hline Aylar & Mayıs & Haziran & Temmuz & Ağustos & Eylül \\
\hline $\mathrm{T}\left({ }^{\circ} \mathrm{C}\right)$ & 13.2 & 17.7 & 20.2 & 20.7 & 16.3 \\
\hline $\mathrm{T}_{\max }\left({ }^{\circ} \mathrm{C}\right)$ & 18.8 & 24.0 & 26.4 & 27.7 & 23.2 \\
\hline $\mathrm{T}_{\min }\left({ }^{\circ} \mathrm{C}\right)$ & 7.5 & 11.5 & 13.9 & 13.7 & 9.4 \\
\hline $\mathrm{n}($ saat $)$ & 10.2 & 12.1 & 12.2 & 11.0 & 10.3 \\
\hline $\mathrm{R}_{H}(\%)$ & 50 & 41 & 42 & 33 & 40 \\
\hline $\mathrm{U}_{2}(\mathrm{~km} /$ gün) & 182 & 182 & 180 & 162 & 160 \\
\hline
\end{tabular}

Tablo 4. Su Tüketim Rehberinde Van için verilen $\mathrm{ET}_{\mathrm{o}}$ değerleri ve ceviz bitkisi için önerilen $\mathrm{k}_{\mathrm{c}}$ değerleri

\begin{tabular}{|l|l|l|l|l|l|l|l|l|l|l|l|l|}
\hline Aylar & 1 & 2 & 3 & 4 & 5 & 6 & 7 & 8 & 9 & 10 & 11 & 12 \\
\hline $\begin{array}{l}\text { ET。 } \\
(\mathrm{mm} / \text { gün })\end{array}$ & 0.82 & 1.07 & 1.94 & 3.04 & 4.41 & 5.57 & 6.20 & 5.65 & 4.08 & 2.39 & 1.22 & 0.82 \\
\hline $\mathrm{k}_{\mathrm{c}}$ & - & - & 0.61 & 0.84 & 1.06 & 1.13 & 1.14 & 1.11 & 1.03 & 0.82 & - & - \\
\hline
\end{tabular}

\section{Bulgular ve Tartışma}

Van ili aylık uzun yıllar ortalaması iklim verileri ve CROPWAT yazılımı kullanılarak 12 aylık gerçek referans evapotranspirasyon $\left(\mathrm{ET}_{\mathrm{o}}\right)$ miktarları belirlenmiş ve Şekil 2'de verilmiştir. Maksimum ve minimum hava sıcaklıkları $\left(T_{\max }, T_{\min }\right)$, oransal nem $\left(R_{H}\right), 2$ m yükseklikten ölçülen rüzgar hızı $\left(U_{2}\right)$ ve 
günlük güneşlenme süresi (n) verileri yazılıma girilerek solar radyasyon ( $\mathrm{R}_{S}$ ) ve referans evapotranspirasyon $\left(\mathrm{ET}_{\mathrm{o}}\right)$ değerleri hesaplanmıştır. Enlem (Latitude) ve boylam (Longitude) yazılıma derece cinsinden girilmiştir. Dolayisıyla enlem $38^{\circ}+(28 / 60)^{\circ}=38.47^{\circ}$, boylam $43^{\circ}+(20 / 60)^{\circ}=43.33^{\circ}$ işlemleri ile dereceye çevrilmiştir.

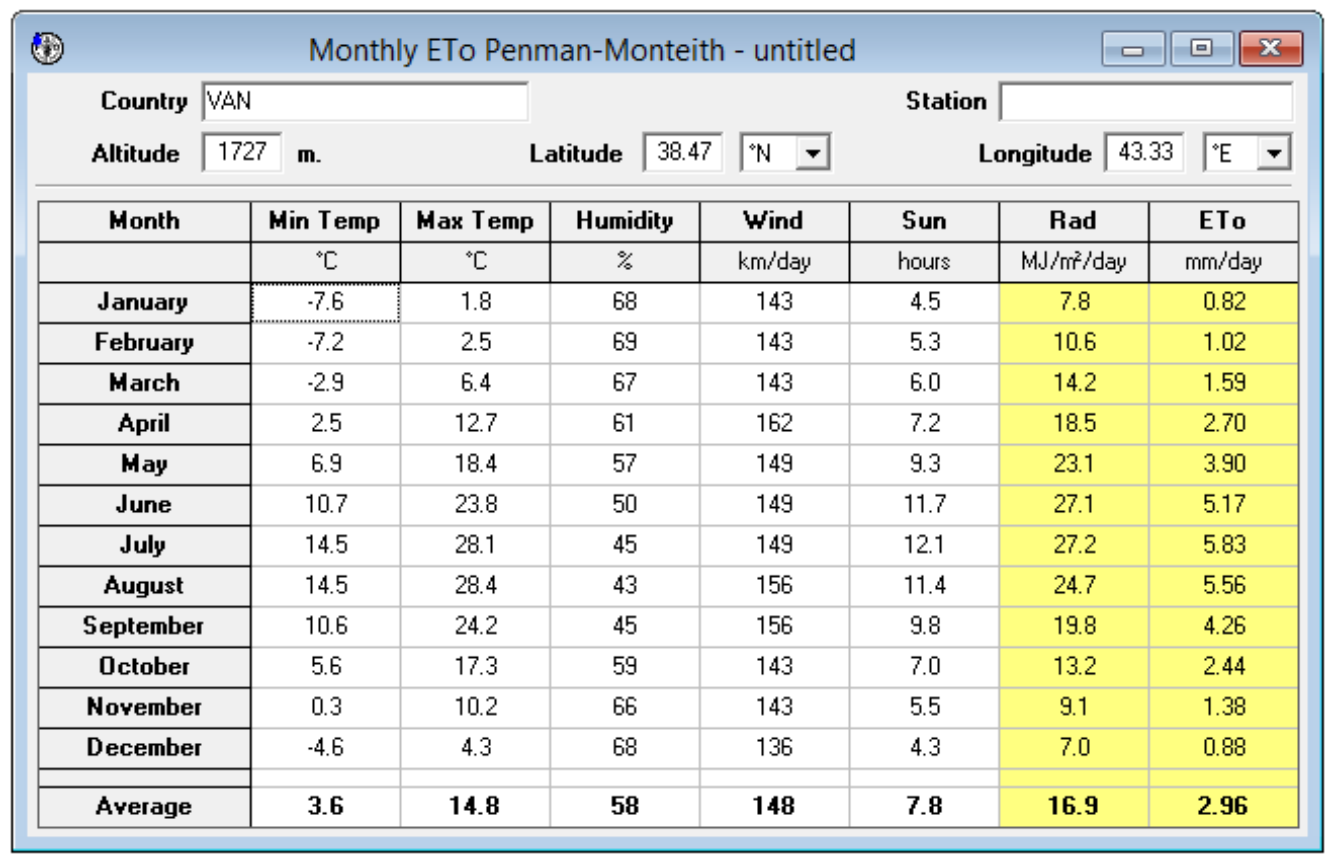

Şekil 2. CROPWAT yazılımı ile elde edilen aylık ortalama günlük $\mathrm{ET}_{\mathrm{o}}$ miktarları

Hesaplamalar sonucunda elde edilen gerçek $\mathrm{ET}_{\mathrm{o}}$ değerleri ile iklim parametrelerinin aylara göre değişimi Şekil 3'de gösterilmiştir. Hava sıcaklığı (T) ve güneşlenme süresinin (n) maksimum değerlere çıktığı, buna karşın oransal nemin $\left(\mathrm{R}_{\mathrm{H}}\right)$ minimum değerlere düştüğü Haziran, Temmuz, Ağustos ve Eylül aylarında $\mathrm{ET}_{\mathrm{o}}$ 'n en yüksek değerlerine ulaştı̆ı, maksimum su tüketiminin ise $5.83 \mathrm{~mm} /$ gün değeri ile Temmuz ayında gerçekleşebileceği görülmüsştür. $T$ ve $n$ değerlerinin minimuma düştüğü, buna karşın $R_{H}$ değerinin maksimuma çıktığı Aralık, Ocak ve Şubat aylarında $\mathrm{ET}_{\mathrm{o}}$ 'ın en küçük değerlerine düştüğü, minimum su tüketiminin ise $0.82 \mathrm{~mm} /$ gün değeri ile Ocak ayında gerçekleşebileceği görülmüş̧ür.

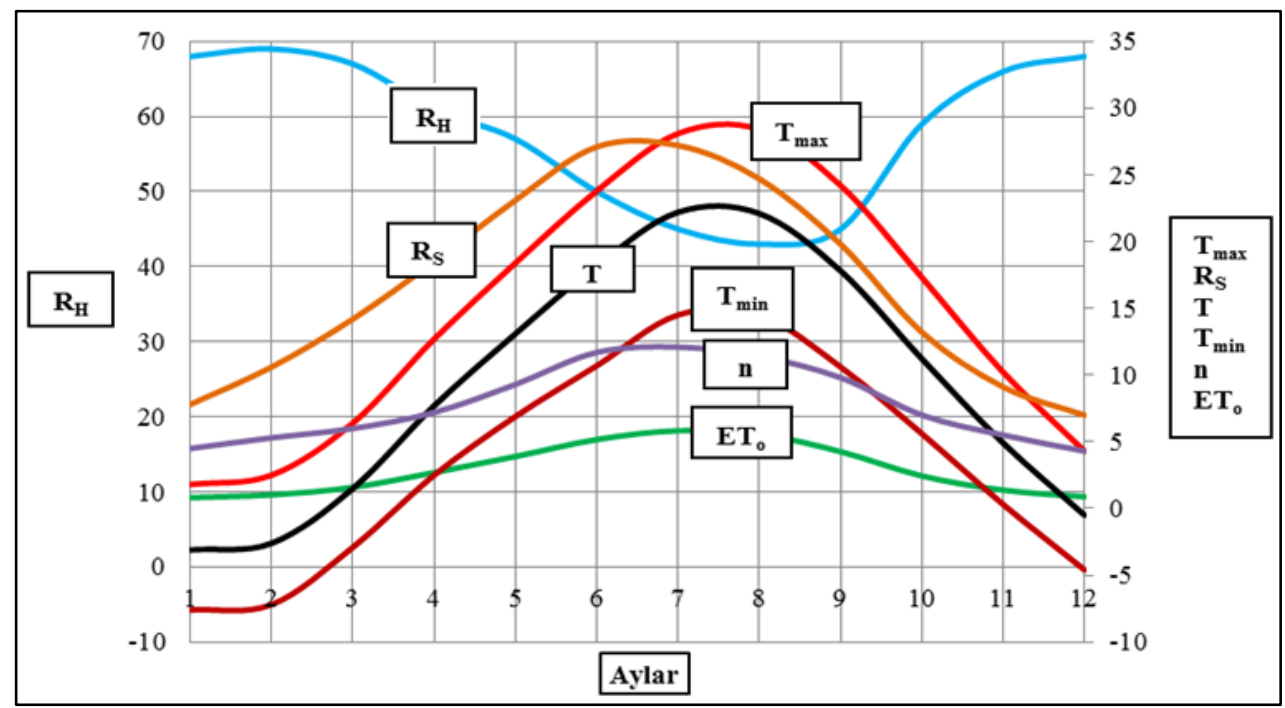

Şekil 3. Van ili iklim parametreleri ve referans evapotranspirasyonun $\left(\mathrm{ET}_{\mathrm{o}}\right)$ aylara göre değişimi 
Ortalama hava sıcaklığı $(\mathrm{T})$, maksimum hava sıcaklığı $\left(\mathrm{T}_{\max }\right)$, minimum hava sıcaklığı $\left(\mathrm{T}_{\min }\right)$ ve oransal nem $\left(R_{H}\right)$ parametrelerinin çeşitli kombinasyonları kullanılarak geliştirilen ÇDRM ${ }_{1}, C_{C R M}$ ve $C_{\text {DRM }}{ }_{3}$ çoklu doğrusal regresyon modelleri için referans evapotranspirasyon $\left(\mathrm{ET}_{\mathrm{o}}\right)$ tahmininde kullanılabilecek tahmin eşitlikleri oluşturularak toplu halde Tablo 5'de verilmiştir. ÇDRM 2 ve $\mathrm{CCDR}_{3}$ modellerinin her ikisinin de $\mathrm{ET}_{\mathrm{o}}$ ile ilişki düzeyini ifade eden korelasyon katsayıları $\mathrm{r}=0.99$ olup, referans evapotranspirasyondaki değişimin \% 99'unun $\left(\mathrm{R}^{2}=0.99\right)$ bu iki model tarafindan açıklanabildiği ortaya koyulmuştur. $\mathrm{T}, \mathrm{T}_{\max }$ ve $\mathrm{T}_{\min }$ parametrelerinin bağımsız değişkenler olarak dikkate alındığ $1 \mathrm{ÇDRM}_{2}$ modelinde standart hata 0.178 olarak belirlenmiştir. $T, T_{\max }, T_{\min }$ ve $R_{H}$ parametrelerinin bağımsız değişkenler olarak dikkate alındığı ÇDRM ${ }_{3}$ modelinde ise standart hata 0.183 olarak belirlenmiştir. $\mathrm{Bu}$ hata miktarları göz önünde bulundurulduğunda $\mathrm{ET}_{\mathrm{o}}$ ile ilişki düzeyi en yüksek olan çoklu doğrusal regresyon modelinin standart hata miktarı daha az olan $\mathrm{ÇDRM}_{2}$ modeli olduğu açıkça görülmektedir. $\mathrm{ÇDRM}_{1}$ modelinin $\mathrm{ET}_{\mathrm{o}}$ ile ilişki düzeyi $\mathrm{ÇDRM}_{2}$ ve $\mathrm{ÇDRM}_{3}$ modellerine göre biraz daha düşük seviyededir. ÇDRM $\mathrm{C}_{1}$ modelinin korelasyon katsayısı $\mathrm{r}=0.98$ olup, referans evapotranspirasyondaki değişimin \% 95'i $\left(\mathrm{R}^{2}=0.95\right)$ bu model tarafından açıklanabilmektedir. Geliştirilen çoklu doğrusal

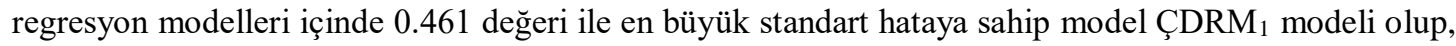
bu modelin $\mathrm{ET}_{\mathrm{o}}$ ile ilişki düzeyi ÇDRM $\mathrm{C}_{2}$ ve ÇDRM 3 modellerine göre daha düşük seviyededir.

Tablo 5. Çoklu doğrusal regresyon modelleri ve tahmin eşitlikleri

\begin{tabular}{|l|c|l|l|l|}
\hline Model & Tahmin eşitliği & $R^{2}$ & $r$ & $S$ \\
\hline ÇDRM $_{1}$ & $\widehat{E T}_{0}=4.919+(0.139 \mathrm{~T})-\left(0.056 \mathrm{R}_{\mathrm{H}}\right)$ & 0.95 & 0.98 & 0.461 \\
\hline ÇDRM $_{2}$ & $\widehat{E T}_{\mathrm{o}}=1.609+(1.847 \mathrm{~T})-\left(0.865 \mathrm{~T}_{\max }\right)-\left(0.865 \mathrm{~T}_{\min }\right)$ & 0.99 & 0.99 & 0.178 \\
\hline $\mathrm{ÇDRM}_{3}$ & $\widehat{\mathrm{ET}}_{\mathrm{o}}=4.138+(1.801 \mathrm{~T})-\left(0.932 \mathrm{~T}_{\max }\right)-\left(0.761 \mathrm{~T}_{\min }\right)-\left(0.026 \mathrm{R}_{\mathrm{H}}\right)$ & 0.99 & 0.99 & 0.183 \\
\hline
\end{tabular}

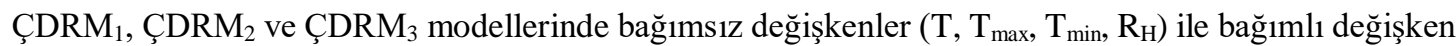
$\left(\mathrm{ET}_{\mathrm{o}}\right)$ arasında doğrusal bir ilişki olup olmadığını kontrol etmek amacıyla \% 95 güven aralığında ve \% 5 $(\alpha=0.05)$ anlamlılık düzeyinde $\mathrm{t}$ ve $\mathrm{f}$ testleri yapılarak elde edilen sonuçlar toplu halde Tablo 6'da verilmiştir. Geliştirilen modellerin hepsinde $t>t_{\text {kritik }}$ ve $f>f_{\text {kritik }}$ şartları sağlandığından dolayı $\mathrm{H}_{\mathrm{o}}$ hipotezi reddedilmiştir. $\mathrm{H}_{1}$ hipotezi kabul edilerek geliştirilen tüm çoklu doğrusal regresyon modellerinde bağımlı değişken $\left(E_{0}\right)$ ile bağımsız değişkenler $\left(T, T_{\max }, T_{\min }, R_{H}\right)$ ) arasında doğrusal bir ilişki olduğu ortaya koyulmuştur. Açıklanan değişimin açıklanamayan değişime oranı olan f değeri ÇDRM $\mathrm{M}_{2}$ modeli için 416.93 ve $\mathrm{CCDRM}_{3}$ modeli için 295.10 olup; bu değerler istatiksel olarak önemli görülmüştür.

Tablo 6. Çoklu doğrusal regresyon modelleri için t ve f testi sonuçları

\begin{tabular}{|l|l|l|l|l|l|}
\hline Model & $\mathrm{t}$ & $\mathrm{t}_{\text {kritik }}$ & $\mathrm{f}$ & $\mathrm{f}_{\text {kritik }}$ & $\alpha / 2$ \\
\hline ÇDRM $_{1}$ & 14.177 & 2.228 & 201.00 & 4.96 & 0.025 \\
\hline ÇDRM $_{2}$ & 20.42 & 2.228 & 416.93 & 4.96 & 0.025 \\
\hline ÇDRM $_{3}$ & 17.18 & 2.228 & 295.10 & 4.96 & 0.025 \\
\hline
\end{tabular}

$\mathrm{ÇDRM}_{1}, \mathrm{ÇDRM}_{2}$ ve ÇDRM$_{3}$ çoklu regresyon modellerine ait tahmin eşitlikleri ile referans evapotranpirasyonun tahmini değerleri $\left(\widehat{\mathrm{ET}}_{\mathrm{o}}\right)$ hesaplanarak sonuçlar toplu halde Tablo 7 'de verilmiştir. FAO 56 Penman Monteith eşitliğine göre CROPWAT yazılımı kullanılarak belirlenen gerçek $\mathrm{ET}_{\mathrm{o}}$ değerleri ile çoklu doğrusal regresyon modelleri kullanılarak hesaplanan $\widehat{E T}_{o}$ değerlerinin aylara göre değişimi ise Şekil 4'de verilen grafiklerde gösterilmiştir. ÇDRM ${ }_{2}$ modeli tahmin eşitliği ile gerçek referans evapotranspirasyon değerlerine en yakın sonuçların elde edildiği, en fazla sapma miktarının ise $\mathrm{ÇDRM}_{1}$ modelinde meydana geldiği, bunun yanında $\mathrm{ÇDRM}_{2}$ ve $\mathrm{ÇDRM}_{3}$ modelleri ile elde edilen tahmini referans evapotranspirasyon değerlerinin $\left(\widehat{E T}_{\mathrm{o}}\right)$ birbirine çok yakın olduğu Şekil 4'de açıkça görülmektedir. 
Vol.5, No.2, 2019

Tablo 7. Çoklu doğrusal regresyon modelleri ile tahmin edilen referans evapotranspirasyon $\widehat{\left(\mathrm{ET}_{\mathrm{o}}\right)}$ değerleri

\begin{tabular}{|c|c|c|c|c|}
\hline \multirow{2}{*}{ Aylar } & \multirow{2}{*}{$\begin{array}{c}\mathrm{ET}_{\mathrm{o}} \\
(\mathrm{mm} / \mathrm{gün})\end{array}$} & \multicolumn{3}{|c|}{$\widehat{\mathrm{ET}}_{\mathrm{o}}(\mathrm{mm} / \mathrm{gün})$} \\
\cline { 3 - 5 } & 0.82 & 0.68 & 0.90 & 0.89 \\
\hline Oçak & 1.02 & 0.69 & 0.87 & 0.81 \\
\hline Şubat & 1.59 & 1.38 & 1.35 & 1.34 \\
\hline Mart & 2.70 & 2.57 & 2.68 & 2.68 \\
\hline Nisan & 3.90 & 3.55 & 3.92 & 3.85 \\
\hline Mayıs & 5.17 & 4.65 & 5.38 & 5.29 \\
\hline Haziran & 5.83 & 5.49 & 5.76 & 5.73 \\
\hline Temmuz & 5.56 & 5.58 & 5.32 & 5.32 \\
\hline Ağustos & 4.26 & 4.87 & 4.38 & 4.41 \\
\hline Eylül & 2.44 & 3.17 & 2.49 & 2.39 \\
\hline Ekim & 1.38 & 1.90 & 1.58 & 1.51 \\
\hline Kasım & 0.88 & 1.04 & 0.95 & 0.96 \\
\hline Aralık & & & & \\
\hline
\end{tabular}

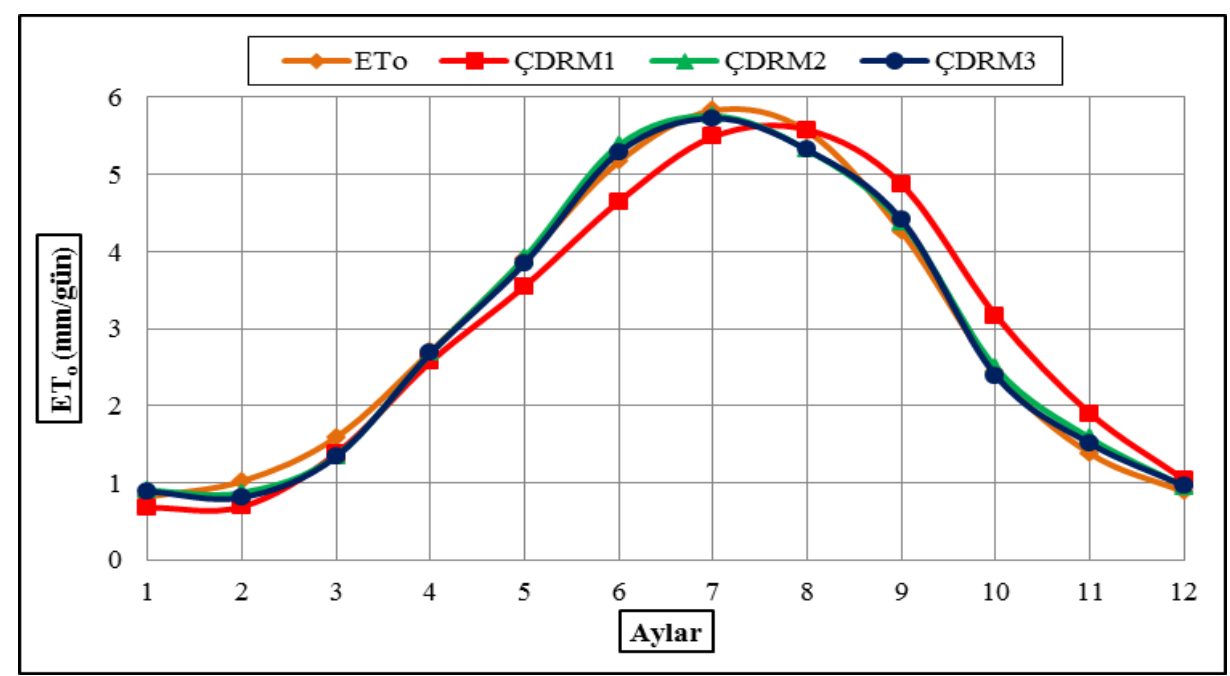

Şekil 4. ÇDRM modelleri ile tahmin edilen $\widehat{\mathrm{ET}}_{\mathrm{o}}$ değerleri ve gerçek $\mathrm{ET}_{\mathrm{o}}$ değerlerinin aylara göre değişimi

Modellerle tahmin edilen $\widehat{E T}_{\mathrm{o}}$ değerlerinin, gerçek $\mathrm{ET}_{\mathrm{o}}$ değerlerinden olan sapma miktarlarını belirlemek amaciyla karekök ortalama karesel hata $(\mathrm{KOKH})$ ve ortalama mutlak göreceli hata $(\mathrm{OMGH})$ değerleri belirlenmiştir. KOKH değerleri ÇDRM ${ }_{1}$ için 0.40, ÇDRM $_{2}$ için 0.15 ve ÇDRM $_{3}$ için 0.14 olarak elde edilmiştir. OMGH değerleri ise $\mathrm{CCDRM}_{1}$ modeli için \% 16.06, $\mathrm{CCDR}_{2}$ modeli için \% 6.48 ve $\mathrm{ÇDRM}_{3}$ modeli için \% 6.61 olarak belirlenmiştir. Elde edilen bu sonuçlar modellerin oluşturulmasında dikkate alınan iklim parametresi sayısı arttıkça hata oranlarının azaldığını göstermektedir. Sulama sistemleri ve su iletim yapılarının projelendirilmesinde toplam sulama suyu ihtiyacı dikkate alınmaktadır. Sulama suyu ihtiyacı ise, sulama alanındaki bitki desenine bağlı olarak vejetasyon süresi boyunca meydana gelebilecek toplam bitki su tüketimi dikkate alınarak belirlenmektedir. Ekim-dikim tarihinden başlayarak 
hasat tarihine kadar geçen toplam süre olarak tanımlanan vejetasyon süresi, Van yöresinde yetiştirilen bitkiler için ortalama Mart ayında başlayarak Ekim ayı sonunda bitmektedir (Anonim, 2016). Bu süre boyunca KOKH değerleri ÇDRM $\mathrm{C}_{1}$ için 0.16 , ÇDRM 2 ve ÇDRM 3 için 0.12 olarak elde edilmiştir. OMGH değerleri ise $\mathrm{CCDRM}_{1}$ modeli için \% 10.94, ÇDRM 2 modeli için \% 3.85 ve ÇDRM ${ }_{3}$ modeli için \% 3.96 olarak belirlenmiştir. Bu sonuçlar, vejetasyon süresi boyunca modellerle tahmin edilen $\widehat{\mathrm{ET}}_{\mathrm{o}}$ değerlerinin tutarlılı̆̆ının arttığını göstermektedir.

$\mathrm{ÇDRM}_{1}, \mathrm{CCDRM}_{2}$ ve $\mathrm{ÇDRM}_{3}$ modellerini test etmek amacıyla, ilk olarak günlük referans bitki su tüketimi $\left(\mathrm{ET}_{\mathrm{o}}\right)$ tahmininde kullanılabilirlik düzeyleri belirlenmiştir. Bu amaçla Van yöresinde 2016 yılının Mayıs, Haziran, Temmuz, Ağustos ve Eylül aylarının on beşinci günlerinde meydana gelen günlük referans bitki su tüketimi $\left(\mathrm{ET}_{\mathrm{o}}\right)$ miktarları önce FAO 56 Penman Monteith eşitliğiyle, daha sonra modellerle hesaplanarak elde edilen $\mathrm{ET}_{\mathrm{o}}$ ve $\widehat{\mathrm{ET}}_{\mathrm{o}}$ değerleri Tablo 8'de verilmiştir. Modellerle tahmin edilen $\widehat{\mathrm{ET}}_{\mathrm{o}}$ değerlerinin, gerçek $\mathrm{ET}_{\mathrm{o}}$ değerlerinden olan sapma miktarlarının bir ifadesi olarak KOKH değerleri $\mathrm{ÇDRM}_{1}$ için $0.52, \mathrm{CCDRM}_{2}$ için 1.75 ve $\mathrm{ÇDRM}_{3}$ için 1.53 olarak elde edilmiştir. OMGH değerleri ise $\mathrm{ÇDRM}_{1}$ modeli için \% $10, \mathrm{ÇDRM}_{2}$ modeli için \% 28.03 ve ÇDRM $\mathrm{C}_{3}$ modeli için \% 24.17 olarak belirlenmiştir. FAO 56 Penman Monteith eşitliğine göre günlük referans bitki su tüketimi tahmininde, 24 saatlik süre boyunca anlık olarak ölçülen hava sıcaklığı, oransal nem, solar radyasyon, güneşlenme süresi, rüzgar hızı ve toprak sıcaklığı iklim parametreleri giriş değişkeni olarak kullanılmaktadır. Van koşullarında bu iklim parametrelerinden sadece hava sıcaklığı ve oransal nemin uzun yıllar ortalamaları dikkate alınarak doğrusal regresyon yöntemiyle geliştirilen $\mathrm{ÇDRM}_{1}, \mathrm{ÇDRM}_{2}$ ve $\mathrm{ÇDRM}_{3}$ modelleriyle tahmin edilen günlük $\widehat{E T}_{\mathrm{o}}$ değerleri, günlük gerçek $\mathrm{ET}_{\mathrm{o}}$ değerlerinden çok farklı elde edilmiştir. İklim parametrelerinin yıl hatta gün bazında farklılıklar göstermesi nedeniyle $\mathrm{ÇDRM}_{1}, \mathrm{CCDRM}_{2}$ ve $\mathrm{ÇDRM}_{3}$ modellerinin günlük referans bitki su tüketimi tahmininde sağlıklı sonuçlar vermediği düşünülmektedir. En düşük KOKH seviyesine sahip olan $\mathrm{ÇDRM}_{1}$ modelinin \% $10 \mathrm{OMGH}$ oranı ile günlük $\mathrm{ET}_{\mathrm{o}}$ tahmininde kullanılabileceği görülmektedir.

Tablo 8. 2016 yılında ilgili ayların on beşinci günleri için günlük referans evapotranspirasyon miktarları

\begin{tabular}{|c|c|c|c|c|}
\hline \multirow{2}{*}{ Aylar } & \multirow{2}{*}{ ET $_{\mathrm{o}}(\mathrm{mm} / \mathrm{gün})$} & \multicolumn{3}{|c|}{$\widehat{\mathrm{ET}}_{\mathrm{o}}(\mathrm{mm} / \mathrm{gün})$} \\
\cline { 3 - 5 } & & $\mathrm{ÇDRM}_{1}$ & ÇDRM $_{2}$ & ÇDRM $_{3}$ \\
\hline Mayıs & 4.34 & 3.95 & 3.24 & 3.38 \\
\hline Haziran & 5.67 & 5.08 & 3.59 & 3.83 \\
\hline Temmuz & 5.95 & 5.38 & 4.06 & 4.24 \\
\hline Ağustos & 5.63 & 5.95 & 4.03 & 4.32 \\
\hline Eylül & 4.29 & 4.95 & 3.52 & 3.68 \\
\hline
\end{tabular}

ÇDRM modellerini test etmek amacıyla, ikinci olarak bu modellerin vejetasyon süresi boyunca meydana gelebilecek toplam bitki su tüketimi $\left(\Sigma \mathrm{ET}_{\mathrm{c}}\right)$ miktarının belirlenmesinde kullanılabilirlik düzeyleri belirlenmiştir. İlk olarak modeller ile tahmin edilen $\widehat{E T}_{0}$ değerleri, Türkiye'de Sulanan Bitkilerin Su Tüketim Rehberinde Van için verilen $\mathrm{ET}_{\mathrm{o}}$ değerleri ile karşılaştırılarak KOKH ve OMGH değerleri belirlenmiştir. KOKH değerleri ÇDRM $\mathrm{C}_{1}$ için $0.62, \mathrm{ÇDRM}_{2}$ için 0.34 ve $\mathrm{CCDRM}_{3}$ için 0.35 olarak elde edilmiştir. OMGH değerleri ise $\mathrm{CCDRM}_{1}$ için \% 23.35, ÇDRM $\mathrm{C}_{2}$ için \% 12.92 ve ÇDRM $\mathrm{C}_{3}$ için \% 12.97 olarak belirlenmiştir. Vejetasyon süresi boyunca KOKH değerleri ÇDRM $\mathrm{K}_{1}$ için $0.57, \mathrm{CCDRM}_{2}$ için 0.31

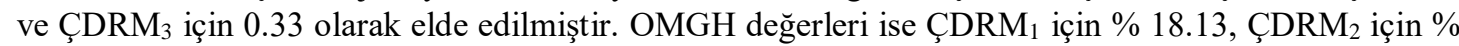
10.16 ve $\mathrm{CCDRM}_{3}$ için \% 10.25 olarak belirlenmiştir. Bu sonuçlar, ÇDRM $\mathrm{C}_{2}$ ve $\mathrm{ÇDRM}_{3}$ ile tahmin edilen $\widehat{E T}_{o}$ değerlerinin Su Tüketim Rehberinde Van için verilen $\mathrm{ET}_{\mathrm{o}}$ değerleriyle iyi sayılabilecek bir düzeyde uyumlu olduğunu, $\mathrm{ÇDRM}_{1}$ ile tahmin edilen $\widehat{\mathrm{ET}}_{\mathrm{o}}$ değerlerinin ise daha düşük düzeyde bir uyuma sahip olduğu göstermektedir.

Sulama sistemleri ve su iletim yapılarının projelendirilmesinde, sulama alanındaki bitki desenine bağlı olarak vejetasyon süresi boyunca meydana gelebilecek toplam bitki su tüketimi $\left(\Sigma \mathrm{ET}_{\mathrm{c}}\right)$ dikkate alınmaktadır. ÇDRM modellerinin $\Sigma E T_{c}$ miktarının belirlenmesinde kullanılabilirliklerini test etmek amacıyla, Van yöresinde yetiştirilen ceviz bitkisinin toplam bitki su tüketimi üzerine hesaplamalar yapılmıştır. Ceviz bitkisinin toplam bitki su tüketimi ( $\left.\Sigma E T_{c}\right)$, önce ÇDRM modellerine göre daha sonra Su Tüketim Rehberine göre belirlenerek elde edilen sonuçlar karşılaştırılmıştır. Vejetasyon süresinin başlangıç tarihi 10 Mart, bitiş tarihi 30 Ekim olarak dikkate alınmıştır (Anonim, 2016). Cevizin bitkisinin

15 | $\mathrm{P}$ a g e

www.iiste.org 
aylık bitki su tüketimi miktarları ilk olarak ÇDRM modelleri ile hesaplanarak elde edilen $\widehat{E T}_{\mathrm{c}}$ miktarları Tablo 9'da verilmiştir. Daha sonra Su Tüketim Rehberine göre aylık ET ${ }_{\mathrm{c}}$ miktarları belirlenerek sonuçlar Tablo 10'da verilmiştir.

Tablo 9. Ceviz bitkisinin $\mathrm{ÇDRM}_{1}, \mathrm{CCDRM}_{2}$ ve $\mathrm{ÇDRM}_{3}$ modelleri ile tahmin edilen $\widehat{\overline{\mathrm{ET}}} \mathrm{c}$ değerleri

\begin{tabular}{|c|c|c|c|c|c|c|c|c|}
\hline \multirow{2}{*}{ Aylar } & \multicolumn{3}{|c|}{$\widehat{\mathrm{ET}}_{\mathrm{o}}(\mathrm{mm} / \mathrm{gün})$} & \multirow{2}{*}{$\mathrm{k}_{\mathrm{c}}$} & \multirow{2}{*}{$\begin{array}{c}\text { Süre } \\
\text { (Gün) }\end{array}$} & \multicolumn{3}{|c|}{$\widehat{\mathrm{ET}}_{\mathrm{c}}(\mathrm{mm})$} \\
\hline & $\mathrm{ÇDRM}_{1}$ & $\mathrm{ÇDRM}_{2}$ & $\mathrm{ÇDRM}_{3}$ & & & $\mathrm{ÇDRM}_{1}$ & $\mathrm{ÇDRM}_{2}$ & $\mathrm{ÇDRM}_{3}$ \\
\hline Mart & 1.38 & 1.35 & 1.34 & 0.61 & 20 & 16.84 & 16.47 & 16.35 \\
\hline Nisan & 2.57 & 2.68 & 2.68 & 0.84 & 30 & 64.76 & 67.54 & 67.54 \\
\hline Mayıs & 3.55 & 3.92 & 3.85 & 1.06 & 30 & 112.89 & 124.66 & 122.43 \\
\hline Haziran & 4.65 & 5.38 & 5.29 & 1.13 & 30 & 157.64 & 182.38 & 179.33 \\
\hline Temmuz & 5.49 & 5.76 & 5.73 & 1.14 & 30 & 187.76 & 196.99 & 195.97 \\
\hline Ağustos & 5.58 & 5.32 & 5.32 & 1.11 & 30 & 185.82 & 177.16 & 177.16 \\
\hline Eylül & 4.87 & 4.38 & 4.41 & 1.03 & 30 & 150.48 & 135.34 & 136.27 \\
\hline Ekim & 3.17 & 2.49 & 2.39 & 0.82 & 30 & 77.98 & 61.25 & 58.79 \\
\hline & & & & & $\widehat{\overline{\Sigma \mathrm{ET}_{\mathrm{c}}}}$ & 954.17 & 961.79 & 953.84 \\
\hline
\end{tabular}

Tablo 10. Ceviz bitkisinin Su Tüketim Rehberine göre hesaplanan $\Sigma \mathrm{ET}_{\mathrm{c}}$ değeri

\begin{tabular}{|c|c|c|c|c|}
\hline Aylar & $\mathrm{ET}_{\mathrm{o}}(\mathrm{mm} / \mathrm{gün})$ & $\mathrm{k}_{\mathrm{c}}$ & Süre $(\mathrm{Gün})$ & $\mathrm{ET}_{\mathrm{c}}(\mathrm{mm})$ \\
\hline Mart & 1.94 & 0.61 & 20 & 23.67 \\
\hline Nisan & 3.04 & 0.84 & 30 & 76.61 \\
\hline Mayıs & 4.41 & 1.06 & 30 & 140.24 \\
\hline Haziran & 5.57 & 1.13 & 30 & 188.82 \\
\hline Temmuz & 6.20 & 1.14 & 30 & 212.04 \\
\hline Ağustos & 5.65 & 1.11 & 30 & 188.15 \\
\hline Eylül & 4.08 & 1.03 & 30 & 126.07 \\
\hline Ekim & 2.39 & 0.82 & 30 & $5 \mathrm{ET}_{\mathrm{c}}=1014.39 \mathrm{~mm}$ \\
\hline
\end{tabular}

Modellerle tahmin edilen toplam bitki su tüketimi değerleri ( $\left(\widehat{\Sigma E T}_{\mathrm{c}}\right) ; \mathrm{ÇDRM}_{1}$ modeline göre $954.17 \mathrm{~mm}$, $\mathrm{ÇDRM}_{2}$ modeline göre $961.79 \mathrm{~mm}$ ve $\mathrm{ÇDRM}_{3}$ modeline göre $953.84 \mathrm{~mm}$ olarak belirlenmiştir. Türkiye'de Sulanan Bitkilerin Su Tüketim Rehberine göre hesaplanan toplam bitki su tüketimi miktarı $\left(\Sigma \mathrm{ET}_{\mathrm{c}}\right)$ ise $1014.39 \mathrm{~mm}$ olarak belirlenmiştir. ÇDRM, $\mathrm{CCDRM}_{2}$ ve $\mathrm{ÇDRM}_{3}$ modelleriyle tahmin edilen $\widehat{\Sigma \mathrm{ET}_{\mathrm{c}}}$ miktarlarının, Su Tüketim Rehberine göre hesaplanan toplam bitki su tüketimi $\left(\Sigma \mathrm{ET}_{\mathrm{c}}=1014.39\right.$ mm) miktarından olan sapma miktarlarını belirlemek amacıyla OMGH oranları hesaplanmış ve sırasıyla \% 5.94, \% 5.19 ve \% 5.97 olarak belirlenmiştir. Elde edilen OMGH oranlarının minimum düzeyde olduğu göz önünde bulundurularak $\mathrm{ÇDRM}_{1}, \mathrm{ÇDRM}_{2}$ ve $\mathrm{ÇRM}_{3}$ modelleri ile tahmin edilen $\widehat{\Sigma E T}_{\mathrm{c}}$ değerlerinin, Van koşullarında projelendirilecek sulama sistemleri ile sulama kanalı ve kanalet gibi su iletim yapılarının boyutlandırılmasında ortalama \% 5-6 hata oranıyla kullanılabileceği düşünülmektedir.

\section{Tartışma ve Sonuç}

Bu çalışmada; hava sıcaklığı $\left(\mathrm{T}, \mathrm{T}_{\max }, \mathrm{T}_{\min }\right)$ ve oransal nemin $\left(\mathrm{R}_{\mathrm{H}}\right)$ çeşitli kombinasyonları kullanılarak geliştirilen çoklu doğrusal regresyon modelleri ile Van koşullarında $\mathrm{ET}_{\mathrm{o}}$ miktarının tahmin edilmesi amaçlanmıştır. $\mathrm{Bu}$ amaç doğrultusunda $\mathrm{ÇDRM}_{1}, \mathrm{CCDRM}_{2}$ ve $\mathrm{ÇDRM}_{3}$ modelleri geliştirilmiştir. ÇDRM

16 | $P$ a g e

www.iiste.org 
modelleri için $\widehat{E T}_{0}=4.919+(0.139 \mathrm{~T})-\left(0.056 \mathrm{R}_{\mathrm{H}}\right), \quad \widehat{E T}_{\mathrm{o}}=1.609+(1.847 \mathrm{~T})-\left(0.865 \mathrm{~T}_{\max }\right)-(0.865$ $\left.\mathrm{T}_{\min }\right)$ ve $\widehat{E T}_{\mathrm{o}}=4.138+(1.801 \mathrm{~T})-\left(0.932 \mathrm{~T}_{\max }\right)-\left(0.761 \mathrm{~T}_{\min }\right)-\left(0.026 \mathrm{R}_{\mathrm{H}}\right)$ tahmin eşitlikleri oluşturulmuştur. Modellerin $\mathrm{ET}_{\mathrm{o}}$ ile ilişki düzeyini ifade eden korelasyon katsayıları ÇDRM ${ }_{2}$ ve $\mathrm{ÇDRM}_{3}$ için $0.99, C_{D R M}$ için 0.98 olarak elde edilmiştir. Referans evapotranspirasyondaki değişimin \% 99'unun $\left(\mathrm{R}^{2}=0.99\right) \mathrm{CCRR}_{2}$ ve ÇDRM ${ }_{3}$ modelleriyle açıklanabildiği ortaya koyulmuştur. En az bağımsız değişkenin dikkate alındığı ÇDRM $\mathrm{CM}_{1}$ modelinde ise bu oran \% $95\left(\mathrm{R}^{2}=0.95\right)$ olarak elde edilmiştir.

Modelle tahmin edilen $\widehat{E T}_{o}$ değerinin, FAO 56 Penman Monteith eşitliği ile belirlenen $\mathrm{ET}_{0}$ değerinden olan sapma miktarının bir ifadesi olarak KOKH değerleri ÇDRM ${ }_{2}$ ve ÇDRM ${ }_{3}$ için 0.12 , ÇDRM1 için 0.16 olarak elde edilmiştir. OMGH oranları ise ÇDRM ${ }_{1}$ için \% 10.94, ÇDRM ${ }_{2}$ için $\% 3.85$ ve ÇDRM 3 için \% 3.96 olarak belirlenmiştir. Elde edilen bu oranlar, modellerin oluşturulmasında dikkate alınan iklim parametresi sayısı arttıkça, modeller ile hesaplanan $\widehat{E T}_{0}$ değerlerinin tutarllığının arttığını göstermektedir.

Anlık iklim verilerinin yıldan yıla farklılıklar gösterebilmesi nedeniyle ÇDRM modellerinin günlük $E_{0}$ tahmininde sağlıklı sonuçlar vermediği düşünülmektedir. Sadece en düşük hata oranlarına $(\mathrm{KOKH}=0.52$, $\mathrm{OMGH}=\% 10$ ) sahip olan $\mathrm{ÇDRM}_{1}$ modelinin günlük $\mathrm{ET}_{0}$ tahmininde kullanılması önerilmektedir. FAO 56 Penman Monteith eşitliğine nazaran, daha az sayıda iklim parametresinin dikkate alındığ ÇDRM $_{1}$, $\mathrm{CCDRM}_{2}$ ve $\mathrm{ÇDRM}_{3}$ modelleri ile tahmin edilen $\widehat{E T}_{\mathrm{o}}$ değerlerinin Van koşullarında \% 5-6 OMGH oranıyla $\Sigma \mathrm{ET}_{\mathrm{c}}$ tayininde kullanılabileceği sonucuna varılmıştır. Ayrıca bu modellerin yöreye uygun olmaları nedeniyle iyi birer alternatif olacakları düşünülmektedir.

\section{Kaynaklar}

Akgül, A., Çevik, O. (2003). Istatistiksel Analiz Tek. SPSS'te İşletme Yönetimi Uyg. Emek Ofset, Ankara.

Allen, R.G., Pereira, L.S., Raes, D., Smith, M. (1998). CropEvapotrans. Guidelines for Computing Crop Water Requirements. FAO Irrigation and Drainage Paper 56, 300 p., Foodand Agric. Org., Rome.

Allen, R.G. (2015). REF-ET: Reference Evapotranspuratıon Calculatıon Software for FAO and ASCE Standardized Equations. User Manuel, 92 p., University of Idaho.

Amayreh, J., Al-Abed, N. (2005). Developing Crop Coefficients for Field-Grown Tomato Under Drip Irrigation With Black Plastic Mulch. Agricultural Water Management, 73(3), 247-254.

Anonim, (2016). Türkiye'de Sulanan Bitkilerin Bitki Su Tüketimi Rehberi. T.C. Gıda, Tarım ve Hayvancılık Bakanlığı Tarımsal Araştırmalar ve Politikalar Genel Müdürlüğü Yayınları, Ankara.

ASCE-EWRI, (2004). The ASCE Standardized Reference Evapotranspiration Equation. Technical Committee Report to the Environmental and Water Resources Institute of theAmerican Society of Civil Engineers from the Task Committee on Standardization of Reference Evapotranspiration, USA.

Aydinşakir, K., Baştuğ, R., Büyüktaş, D. (2003). Antalya Yöresinde Çim Kıyas Bitki Su Tüketimini Veren Bazı Ampirik Eşitliklerin Tarla ve Lizimetre Koşullarında Kalibrasyonu. Akdeniz Üniversitesi Ziraat Fakültesi Dergisi, 16(1), 107-119.

Bandyopadhyay, A.,Bhadra, A., Swarnakar, R.K., Raghuwanshi, N.S., Singh, R. (2012). Estimation of Reference $\mathrm{ET}_{\mathrm{o}}$ Using a User-Friendly Decision Support System: DSS_ET. Agricultural and Forest Meteorology, 154-155, 19-29.

Beyazgül, M., Kayam, Y., Engelsman, F. (2000). Estimation Methods for Crop Water Requirements in the Gediz Basin of Western Turkey. Journal of Hydrology, 229(1-2), 19-26. 
Beyribey, M., Çakmak, B., Sönmez, F.K., Oğuz, M. (1997). Sulama Şebekelerinde Blaney-Criddle ve Penman-Monteith Yöntemlerine Göre Sulama İhtiyacının Karşılaştırılması. Ankara Üni. Ziraat Fak. Tarım Bil. Dergisi, Cilt 3(1), 74-78.

Büyüköztürk, Ş. (2003). Sosyal Bilimler İçin Veri Analizi El Kitabı. Pegem Yayıncılık, Ankara.

Çetin, Ö., Köksal, E.S., Yıldırım, Y.E., Özaydın, K.A. (2014). Türkiye'de Su Tüketim Rehberi Çalışmaları Kapsamında Bitki Su Tüketimi ve Bitki Katsayllarının Elde Edilmesi. 12. Kültürteknik Sempozyumu, 21-23 Mayıs, Tekirdağ.

Dehghanisanij, H., Yamamotoa, T., Rasiah V. (2004). Assessment of Evapotranspiration Estimation Models for Use in Semi-Arid Environments. Agricultural Water Management, 64, 91-106.

DMİ, (2018). Van Ili 1938-2017 Yılları Arası Aylık Ortalama İklim verileri ile 2016 Yılı Günlük İklim Verileri. Devlet Meteoroloji İşleri Genel Müdürlüğü.

Doğan Demir, A., Meral, R. (2016). Bingöl İli Koşullarında Referans Bitki Su Tüketiminin Doğrudan ve Farklı Tahmin Yöntemleri ile Belirlenmesi. Türk Tarım ve Doğa Bilimleri Dergisi, 3(1), 4551.

Doorenbos, J., Pruitt, W.O. (1977). Crop Water Requirements. FAO Irrig. And Drainage: Paper 24, Rome.

Er-Raki, S., Chehbouni, A., Hoedjes, J., Ezzahar, J., Duchemin, B., Jacob, F. (2008). Improvement of FAO-56 Method for Olive Orchards Through Sequential Assimilation of Thermal InfraredBased Estimates of ET. Agricultural Water Management, 95(3), 309-321.

Gocic, M., Trajkovic, S. (2010). Software for Estimating Reference Evapotranspiration Using Limited Weather Data. Computersand Electronics in Agriculture, 71, 158-162.

Hess, T.M. (1996). Potential Evapotranspiration [DAILYET]. Silsoe College. UK.

Jensen, M.E. (1968). Water Consumption by Agricultural Plants. Academic Press Inc., New York.

Kanber, R. (2006). Sulama. Çukurova Üniversitesi Ziraat Fakültesi Ders Kitapları: Yayın No: A-52, Adana.

Karaca, C., Büyüktaş, D., Sönmez, F.K., Tekelioğlu, B. (2017). Kıyas Bitki Su Tüketiminin (ETo) Hesaplanması Amacıyla Kullanılan Bilgisayar Yazılımlarının Karşılaştııılması. Gaziosmanpaşa Bil. Araş. Dergisi (GBAD), Cilt 6(1), 118-128.

Karaca, C., Büyüktaş, D., Baştuğ, R., Aydınşakir, K., Tekelioğlu, B. (2017). Antalya Koşullarında Kıyas Bitki Su Tüketiminin Alansal ve Zamansal Dağılımının Belirlenmesi. Derim, 34(2),158-171.

Katerji, N., Rana, G. (2014). FAO-56 Methodology for Determining Water Requirements of Irrigated Crops Critical Examination of the Concepts Alternative Proposals and Validation in Mediterranean Region. Theoretical and Applied Climatology, 116(3), 515-536.

Kaya, S., Gökdoğan, O., Doğan Demir, A., Malaslı M.Z. (2013). Sicaklık Verileri Kullanılarak ETo' ’n Belirlenmesi. III. Ulusal Toprak ve Su Kay. Kong., 22-24 Ekim, Bildiriler, 399-407, Tokat.

Kişi, Ö., Af̧̧ar, S. (2010). Yapay Sinir Ağı ve Bulanık-Yapay Sinir Ağı Yöntemleri Kullanılarak Tava Buharlaşma Tahmini. Tarım Bilimleri Araştırma Dergisi, 3(1), 45-51.

Ko, J.,Piccinni, G., Steglich, E. (2009). Using EPIC Model to Manage Irrigated Cotton and Maize. Agricultural Water Management, 96(9), 1323-1331.

18 | P a g e

www.iiste.org 
Kodal, S. (1982). İç Anadolu da Bitki Su Tüketiminin Saptanması İçin Uygun Yöntemin Belirlenmesi Üzerinde Bir Araştırma. Ankara Üniversitesi Ziraat Fak. Kültürteknik Bölümü Doktora Tezi, Ankara.

Köksal, B.A. (1985). İstatistik Analiz Metotları. Çağlayan Kitabevi, İstanbul.

Lazzara, P., Rana, G. (2010). The Crop Coefficient $\left(\mathrm{k}_{\mathrm{c}}\right)$ Values of the Major Crops Grown Under Mediterranean Climate.Med. Dialogue on Integrated Water Man., FP6 INCO-MED Funded Project.

Pereira, L.S., Allen, R.G., Smith, M., Raesda, D.R. (2015). Crop Evapotranspiration Estimation with FAO56: Past and Future. Agricultural Water Management, 147, 4-20.

Raes, D. (2012). Reference Manual-ET $T_{o}$ Calculator. Food and Agriculture Organization of the United Nations Land and Water Division, Paper 37.

Rana, G., Katerji, N. (2000). Measurement and Estimation of Actual Evapotranspiration in theField Under Mediterranean Climate (A review). European Journal of Agronomy, 13(2-3), 125-153.

Sepaskhah, A.R., Andam, M. (2001). Crop Coefficient of Sesame in a Semi-Arid Region of Iran. Agricultural Water Management, 49(1), 51-63.

Steduto, P., Snyder, R.L. (1998). IAM_ET ${ }_{\mathrm{o}}$ Software Program and User's Guide. Options Méditerranéennes: Série B, Etudes et Recherches, 20, 1-64.

Uçak, A.B., Gençoğlan, C., Değirmenci, H. (2013). The Effect of Direct and Traditional Seeding Methods and Different Water Levels on the Water-Yield Relationship of Drip Irrigated Corn. Journal of Food, Agriculture Environment, 11(3-4), 828-833.

Ünver, Ö., Gamgam, H. (1999). Uygulamalı İstatistik Yöntemler. Siyasal Kitabevi, Ankara. 